\title{
KOPOLIMERISASI CANGKOK POLI(KALIUMAKRILAT)- GELATIN HASIL IRADIASI GAMMA
}

\author{
Erizal $^{1}$, Dian Pribadi P. ${ }^{1}$, Evi Yulianti ${ }^{2}$, Sudirman $^{2}$, Hariyanti $^{3}$ dan Fajar lukitowati $^{1}$ \\ ${ }^{1}$ Pusat Aplikasi Isotop dan Radiasi (PAIR) - BATAN \\ Jl. Lebak Bulus Raya No.14, Jakarta 12440 \\ ${ }^{2}$ Pusat Sains dan Teknologi Bahan Maju (PSTBM) - BATAN \\ Kawasan Puspiptek, Serpong 15314, Tangerang Selatan \\ ${ }^{3}$ Fakultas Sains dan Farmasi - Universitas Prof Uhamka \\ Klender, Jakarta Timur \\ E-mail:izza3053 @yahoo.com
}

Diterima: 21 April 2018 Diperbaiki: 22 Mei $2018 \quad$ Disetujui: 10 Juli 2018

\begin{abstract}
ABSTRAK
KOPOLIMERISASI CANGKOK POLI(KALIUMAKRILAT)-GELATIN HASIL IRADIASI GAMMA. Hidrogel Super Absorben (HSA) merupakan polimer yang dapat menyerap air dalam jumlah yang relatif besar ( \pm 1000 kali berat kering) dan salah satu baku penting khususnya untuk popok bayi/dewasa. Satu seri HSA dibuat dari asam akrilat yang telah dinetralkan sebagian dengan $\mathrm{KOH}$, lalu dicangkokan (grafting) dengan gelatin pada konsentrasi $1 \%$ hingga $4 \%(\mathrm{~b} / \mathrm{v}, \%)$ dan diiradiasi menggunakan sinar gamma pada dosis tunggal $10 \mathrm{kGy}$ (laju dosis 2,5 kGy/jam). Terjadi cangkok gelatin pada polimer diukur menggunakan Fourier Transform Infra Red (FT-IR) dan morfologi diobservasi menggunakan Scanning Electron Microscope (SEM). Fraksi gel dan kemampuan hidrogel dalam mempertahankan air yang diserap (rasio swelling) dan Equilibrium Degree of Swelling (EDS) hidrogel ditentukan dengan metode gravimetri. Hasil evaluasi menggunakan SEM, morfologi permukaan HSA hasil iradiasi menunjukkan terjadi cangkok polimer (kalium akrilat) pada molekul gelatin dan hasil pengukuran spektrum FT-IR menunjukkan gugus karboksilat $(\mathrm{COOH})$ yang bereaksi dengan gelatin. Meningkatnya konsentrasi gelatin hingga $4 \%$, rasio swelling, fraksi dan $E D S$ hidrogel juga mengalami peningkatan. Hidrogel HSA poli (kalium akrilat-g-gelatin dapat dipertimbangkan sebagai bahan material kandidat biodegradable hidrogel untuk aplikasi di biang kesehatan/farmasi.
\end{abstract}

Kata kunci : Hidrogel, Superabsorben, Cangkok, Iradiasi, Gelatin

\begin{abstract}
GRAFT COPOLYMERIZATION OF POLY(POTASIUM ACRYLATE-GELATINE PREPARED USING GAMMA RADIATION. Hydrogel superabsorbent (HSA) is a polymer which can absorb a large amount of water $( \pm 1000$ times of its dried weight) relatively, and as one of the importan raw material up to now. A series of (HSA) were prepared from partially neutralized acrylic acid with $\mathrm{KOH}$, then grafted with gelatin at various concentration ( $1-4 \%, \mathrm{w} / \mathrm{v})$ using gamma irradiation at a single dose of $10 \mathrm{kGy}$ (dose rate $2.5 \mathrm{kGy} / \mathrm{h}$ ). The grafted polymer onto gelatine molecules were characterized by Fourier Transform Infra Red (FT-IR), and its morphologies were observed by Scanning Electron Microscope (SEM). Gel fraction, and the water retention (swelling ratio) and Equlibrium Degree of Swelling (EDS) were determined by gravimetric method. After evaluated using SEM, it was shown that on the morphology surface of HSA the polymer (potassium acrylate) was grafted onto molecule gelatin. From FT-IR measurement it was shown that carboxylate site of polymer reacted with gelatin, with increasing gelatin concentration up to $4 \%$, the swelling ratio,gel fraction, and EDS of HSA increases. Hydrogel copoly(potassium acrylate)-gelatin can be considered to be a new biodegradable material in health care and pharmacy.
\end{abstract}

Keywords: Hydrogel, Superabsorbent, Grafting, Irradiation, Gelatin 


\section{PENDAHULUAN}

Hidrogel Super Absorben (HSA) merupakan salah satu jenis produk hidrogel yang penting dalam memenuhi kebutuhan masyarakat di seluruh dunia secara global, khususnya untuk penyerap urin untuk bayi dan orang dewasa. Kebutuhan HSA meningkat dengan meningkat jumlah penduduk terutama jumlah bayi yang lahir. HSA berkarakteristik mampu menyerap air dengan kapasitas yang relatif tinggi yaitu 1 gram berat keringnya dapat menyerap air dengan kapasitas 100 gram hingga 1000 gram. Sesuai dengan perkembangan zaman applikasi HSA tidak hanya untuk keperluan popok, tetapi banyak dikembangkan di bidang kesehatan sebagai bahan dasar wadah bedah (surgical pad), pengemas panas dan dingin (hot and cold theraphy packs), pengendap limbah rumah sakit (medical waste solidification), kertas saniter (sanitary napkins) dan bidang industri sebagai penyerap air pada handuk mandi [1-5]. Lebih jauh lagi, jangkauan aplikasi HSA tidak hanya untuk keperluan tersebut diatas, tetapi juga dapat digunakan sebagai kantong air untuk daerah kering/pertanian, media pertumbuhan jamur, sebagai adsorben limbah zat warna dan ion-ion logam, salju buatan, adsorpsi jamur dan bacteria pada pembalut luka, untuk imobilisasi obat (controlled release of drug) dan urea serta juga digunakan pada bahan kontruksi bangunan [6-8].

Asam akrilat adalah salah satu jenis monomer yang dipakai sebagai basis material untuk pembuatan hidrogel superabsorben $[9,10]$. Potensi asam akrilat sebagai bahan baku superabsorben disebabkan karena gugus anion karboksilat pada molekul yang berfungsi dalam mengikat air. Jika asam akrilat tersebut dinetralkan sebagian dan selanjutnya dipolimerisasikan ikatan silang baik secara kimia dan iradiasi gamma. Jika hidrogel tersebut direndam dalam air, mula-mula air berikatan dengan gugus-gugus anion polimer melalui ikatan hidrogen pada punggung rantai polimernya hingga jenuh sebagai fungsi waktu. Selain itu, terjadi pula daya saling tolak menolak antara gugus-gugus anion sepanjang rantai polimer asam akrilat yang mengakibatkan pori-porinya membesar. Oleh karena itu, semakin banyak air yang dapat masuk ke dalam pori, sedangkan kapasitas swelling (menggembung) hidrogel meningkat secara drastis dapat mencapai 800 gram hingga 1000 gram air yang diserap persatuan 1 gram berat kering dalam waktu relatif singkat \pm 10 menit [11]. Namun demikian salah satu kelemahan asam akrilat adalah bentuk polimer limbahnya yang sukar terdegradasi dan akan memicu polusi pada lingkungan, selain sisa asam akrilatnya sendiri.

Pengembangan HSA dengan bahan dasar pembentuknya bersifat multi komponen khususnya pemakaian polimer alami ramah lingkungan merupakan subjek penting pada segi komersialisasi dan kenyamanan terhadap lingkungan [12,13]. Oleh karena itu, perlu dilakukan modifikasi HSA berbasis asam akrilat sebagai bahan dasar superabsorben yang ramah terhadap lingkungan yaitu menggabungkannya dengan polimer alami yang mudah terdegradasi seperti gelatin.

Gelatin merupakan salah satu jenis protein yang diperoleh dari denaturasi parsial kolagen yang diekstrak dari tulang, jaringan halus, organ tubuh dan beberapa usus binatang seperti sapi, babi, kuda dan juga dapat diperoleh dari sisik ikan $[14,15]$. Gelatin menunjukkan aktivitas biologis karena berasal dari alami, yang memungkinkan dapat digunakan sebagai bahan pembalut luka, scaffold untuk tissue engineering dan pelepasan obat terkendali. Di bidang industri farmasi gelatin umumnya digunakan pada pembuatan kapsul, tablet, pengganti plasma darah (blood plasma substitutes), suppositories and enkapsulasi vitamin. Oleh karena itu, gelatin dapat digunakan sebagai aditif pada pembuatan HSA yang ramah lingkungan.

Pada penelitian ini dilakukan pembuatan HSA berbasis asam akrilat yang dinetralkan parsial digrafting dengan gelatin via iradiasi gamma. Pengaruh konsentrasi gelatin terhadap rasio swelling, fraksi gel, Equilibrium Degree of Swelling (EDS) hidrogel dipelajari. Morfologi permukaan dari HSA diobservasi menggunakan Scanning Electron Microscope (SEM) dan karakterisasi kimia dipelajari menggunakan Fourier Transform Infra $\operatorname{Red}(F T-I R)$.

\section{METODE PERCOBAAN}

\section{Bahan dan Alat}

Monomer asam akrilat. Urea, $\mathrm{NaCl}, \mathrm{KOH}$ buatan Merck. Gelatin diperoleh dari hasil ektraksi sisik ikan. Semua bahan kimia yang dipakai kualitas proanalisis.

\section{Ektraksi Gelatin Limbah Sisik Ikan Kakap Putih}

Kurang lebih $200 \mathrm{~g}$ sisik ikan kakap dibersihkan permukaannya menggunakan air kran hingga bersih dari kotoran yang melekat. Selanjutnya, sisik ikan direndam dalam surfaktan selama \pm 24 jam. Kemudian, sisik ikan dicuci kembali untuk menghilangkan surfaktan yang tertinggal pada permukaan sisik ikan. Sisik ikan direndam dalam air, kemudian direbus dalam autoclave selama 2 jam pada tekanan 1 bar. Air rebusan sisik ikan dipisahkan dari sisik ikan dan air rebusan dikering udara selama 24 jam dan diperoleh film gelatin sisik ikan.

\section{Pembuatan HSA Kopoli(Kalium Akrilat)-g- Gelatin}

Disiapkan satu seri $15 \mathrm{~mL}$ larutan monomer asam akrilat (AA) dalam $50 \mathrm{~mL}$ air suling, selanjutnya larutan dinetralkan parsial dengan $\pm 5,6$ gram $\mathrm{KOH}$, diaduk hingga larutan homogen menggunakan pengaduk magnet. Kemudian disiapkan satu seri larutan gelatin 
dengan variasi berat 1 gram, 2 gram, 3 gram dan 4 gram dalam $45 \mathrm{~mL}$ air yang dipanaskan suhu $70{ }^{\circ} \mathrm{C}$ selama 2 jam. Lalu diaduk menggunakan magnetic stirrer hingga homogen. Masing-masing larutan AA yang telah dinetralkan di campur dengan larutan gelatin dengan variasi berat yang berbeda, diaduk, dihomogenkan dan masing-masing larutan ditambahkan air hingga total larutan menjadi $100 \mathrm{~mL}$. Selanjutnya campuran larutan dikemas dalam kantong plastik polipropilen (PP) ukuran $(10 \times 15) \mathrm{cm}^{2}$, ditutup hingga kedap udara menggunakan mesin sealer dan selanjutnya diiradiasi menggunakan sinar gamma dalam iradiator IRPASENA, PAIR-BATAN pada dosis $10 \mathrm{kGy}$ dengan laju dosis 2,5 kGy/jam.

\section{Pengujian Rasio Swelling Hidrogel}

Pengujian rasio swelling hidrogel dimaksudkan untuk menguji kemampuan dalam menyerap air sebagai fungsi waktu berdasarkan metode yang telah dilakukan oleh beberapa peneliti [16]. Laju swelling hidrogel ditetapkan secara gravimetri. Hidrogel kering (Wo) dengan berat $\pm 10 \mathrm{mg}$ dimasukkan ke dalam $100 \mathrm{~mL}$ air suling (larutan jenis lain), lalu diaduk dengan kecepatan $400 \mathrm{rpm}$ selang waktu pada suhu kamar. Selang waktu tertentu, hidrogel yang telah swelling disaring menggunakan saringan teh $( \pm 100$ mesh $)$. Kemudian air saringan yang keluar dari saringan ditampung dalam beaker hingga tidak ada air yang menetes $( \pm 1$ jam $)$. Volume air yang tertampung dalam beaker diukur $\left(\mathrm{W}_{\mathrm{t}}\right)$ sebagai mewakili air yang diserap hidrogel (swelling). Rasio swelling hidrogel dihitung dengan Persamaan (1).

$$
\text { Rasio Swelling }=\left(\mathrm{W}_{\mathrm{t}}\right) / \mathrm{Wo}
$$

\section{Dimana:}

$$
\begin{aligned}
\mathrm{W}_{\mathrm{o}}= & \text { Berat hidrogel kering awal } \\
\mathrm{W}_{\mathrm{t}}= & \text { Berat hidrogel dalam keadaan swelling } \\
& \text { dalam waktu tertentu }
\end{aligned}
$$

Keadaan hidrogel dalam kesetimbangan swelling selang waktu 24 jam Equilibrium Degree of Swelling $(E D S)$ ditetapkan dengan Persamaan 1. Semua pengerjaan dilakukan secara triplo.

\section{Penentuan Fraksi Gel}

Penentuan fraksi gel untuk menentukan jumlah berat awal sampel yang berupa cairan yang telah berubah menjadi produk akhir padatan setelah proses perlakuan baik secara kimia dan iradiasi yang dihitung dalam nilai prosentase. Nilai fraksi gel menggambarkan kerapatan silang hidrogel [17]. Penentuan fraksi gel dilakukan secara gravimetri. Tiga buah cuplikan hidrogel hasil iradiasi dikeringkan pada suhu $60{ }^{\circ} \mathrm{C}$ hingga berat konstan, lalu ditimbang $\left(\mathrm{W}_{\mathrm{o}}\right)$. Kemudian hidrogel dibungkus dalam kawat kasa ukuran 300 mesh yang telah ditara, lalu direndam dalam air suling hingga terendam sempurna dan selanjutnya dikocok dalam shaker incubator pada kecepatan 100 rpm selama 24 jam pada suhu kamar untuk mengekstrak senyawa-senyawa yang tidak bereaksi akibat perlakuan iradiasi dalam hidrogel, senyawa peroksida yang larut dalam air serta senyawa homopolimer hasil iradiasi gamma. Selanjutnya hidrogel dikeluarkan dari shaker incubator dan dikeringkan kembali dalam oven pada suhu $60{ }^{\circ} \mathrm{C}$ hingga berat konstan, hidrogel kering ditimbang kembali $\left(\mathrm{w}_{1}\right)$. Fraksi gel dihitung dengan Persamaan (2).

$$
\text { Fraksi Gel }=\mathrm{W}_{1} / \mathrm{W}_{\mathrm{o}} \times 100 \%
$$

Dimana:

$$
\begin{aligned}
\mathrm{W}_{\mathrm{o}}= & \text { Berat hidrogel kering awal (gram) } \\
\mathrm{W}_{1}= & \text { Berat hidrogel kering hasil proses } \\
& \text { ekstraksi (gram) }
\end{aligned}
$$

\section{Pengukuran FT-IR}

Pengukuran Fourier Transform Infra Red $(F T-I R)$ untuk mempelajari perubahan yang terjadi pada gugus fungsional senyawa akibat perlakuan. Untuk pengukuran $F T-I R$ dalam peneliian ini digunakan FT-IR Merek Shimadzu IRPrestige-21. Daerah kerja $F T$-IR yang dipakai yaitu pada rentang bilangan gelombang $400 \mathrm{~cm}^{-1}$ hingga $4000 \mathrm{~cm}^{-1}$ dengan jumlah scan 20 dan resolusi $4 \mathrm{~cm}^{-1}$.

\section{Pengukuran SEM}

Morfologi permukaaan dari hidrogel diukur menggunakan Scanning Electron Microscope (SEM), Merck JSM 6510 (JEOL, Jepang) yang beroperasi pada voltase $30 \mathrm{kV}$. Sampel hidrogel dibuat swelling maksimum dalam air. Lalu dibekukan dalam freezer dan selanjutnya diliofilisasi dan sampel keringnya diukur permukaan menggunakan SEM.

\section{HASIL DAN PEMBAHASAN}

\section{Scanning Electron Microscope HSA}

Foto SEM hidrogel pada umumnya memberikan informasi mengenai geometri pori-pori dan ukurannya pada lokasi yang spesifik. Oleh karena itu, foto SEM memberikan informasi yang relevan yang berkaitan dengan homogenitas termasuk jaringan hidrogel. Pada Gambar 1(a) hingga Gambar 1(d) disajikan hasil pengamatan $S E M$ hidrogel superabsorben kopoli (kalium akrilat)-g-gelatin pada konsentrasi gelatin 1\% hasil iradiasi gamma dengan perbesaran berturut-turut 150 kali hingga1500 kali. Terlihat bahwa permukaan hidrogel pada perbesaran 150 kali hingga 250 kali (Gambar 1(a) dan Gambar 1(b)) terdiri atas 2 bagian besar yang sangat jelas yaitu adanya jaringan ikatan silang polimer berbentuk mikropori dan bentuk serabut (gelatin) yang 


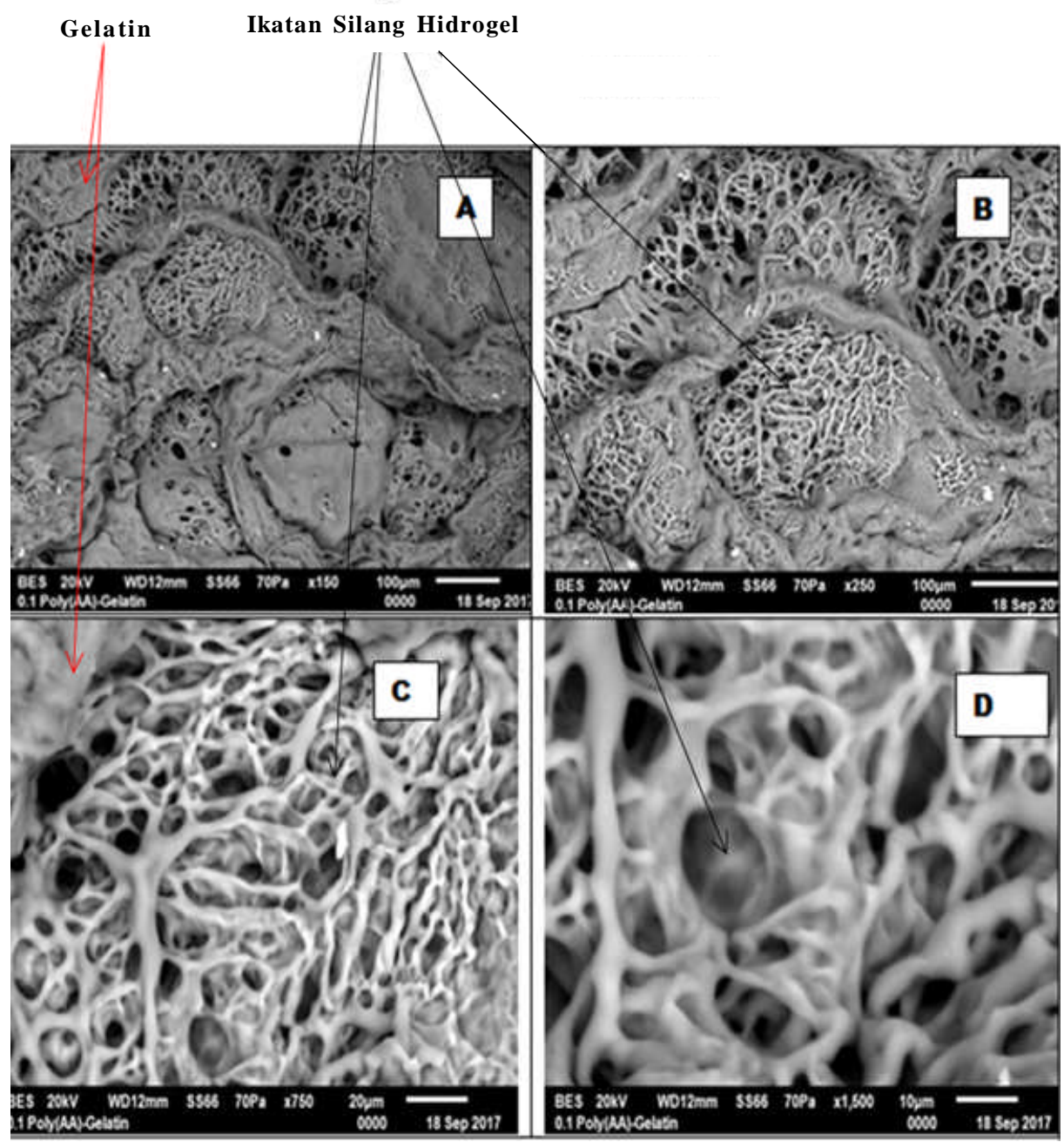

Gambar 1. Foto SEM hidrogel kopoli (kalium-akrilat)-g-gelatin komposisi 10/1 (b/b) hasil iradiasi $10 \mathrm{kGy}$.

menutupi sebagian jaringan ikatan silang hidrogel yang saling terdispersi satu dengan lainnya. Hal ini terjadi disebabkan oleh deposisi polimer secara perlahan-lahan membentuk lapisan jaringan polimer pada permukaan gelatin [9]. Pada pengamatan dengan perbesaran 750 kali hingga 1500 kali, terlihat semakin jelas porositas dari hidrogel yang besar dengan struktur jaringan hidrogel yang tercangkok pada gelatin. Terjadinya porositas yang besar dan tidak teratur ini pada HSA disebabkan polimer poli(kalium akrilat) hasil polimerisasi radiasi tercangkok pada permukaan gelatin.

Sedangkan foto SEM hidrogel dengan konsentrasi gelatin $4 \%$, terlihat bahwa jaringan ikatan silangnya tertutup rapat oleh gelatin (Gambar 2(e) dan Gambar 2(f)). Pori-pori hidrogelnya terbentuk lebih teratur dan halus (Gambar 1(h)), dan gelatin dengan berat molekul yang besar terdispersi pada permukaan jaringan ikatan silang hidrogel (Gambar 2(g)). Terjadinya perbedaan yang jelas dan signifikan pada fotomikrograf SEM antara HSA dengan gelatin $1 \%$ dan HSA yang mengandung gelatin $4 \%$, hal ini mungkin disebabkan pada gelatin konsentrasi $1 \%$ polimer akrilat secara sempurna tercangkok pada gelatin mengakibatkan porinya menjadi tidak teratur. Sedangkan pada HSA yang mengandung gelatin $4 \%$, konsentrasi gelatin yang relatif besar mengakibatkan permukaan HSA jenuh dan porositasnya tidak terganggu.

Proses pencangkokan punggung polimer polisakarida oleh monomer digambarkan berdasarkan mekanisme reaksi diperlihatkan pada Gambar 3 .

A merupakan monomer dan $\mathrm{B}$ adalah polimer polisakarida. Terjadinya reaksi pencangkokan seperti yang diilustrasikan pada Gambar 3 yaitu polisakarida mengalami reaksi pembentukan radikal oleh sebab adanya inisiator. Selanjutnya monomer juga mengalami reaksi pembentukan radikal dan mengalami reaksi polimerisasi dan kemudian bereaksi dengan polimer radikal pada punggungnya (cangkok). Berdasarkan persamaan reaksi tersebut diatas dapat diduga terjadinya reaksi-reaksi yang terjadi dalam campuran asam akrilat -gelatin yang diiradiasi dengan sinar gamma sehingga terbentuk morfologi SEM yang diamati pada Gambar (1) dan Gambar (2). 


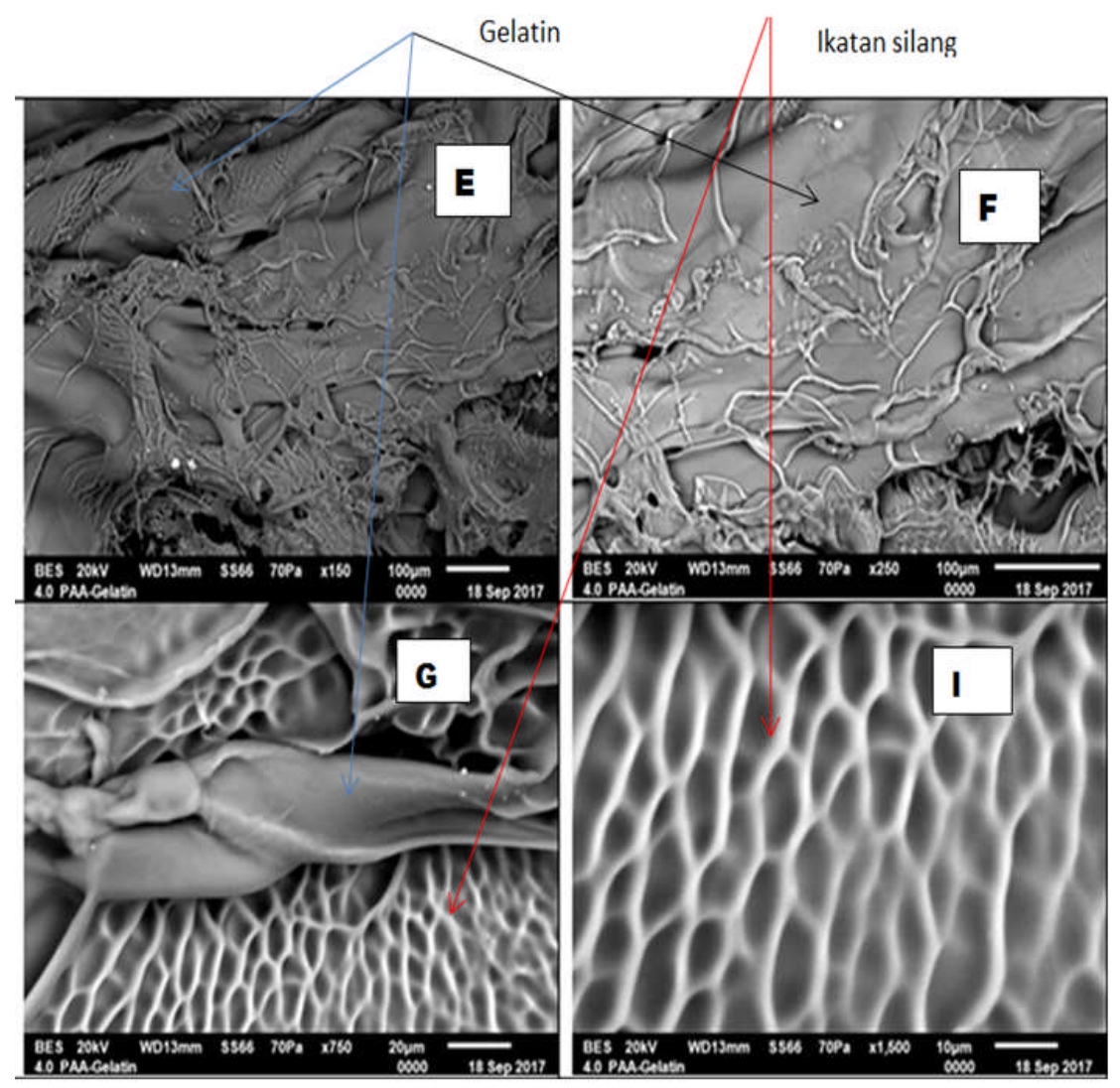

Gambar 2. Foto SEM hidrogel kopoli(kalium-akrilat)-g-gelatin komposisi 10/4 (b/b) hasil iradiasi $10 \mathrm{kGy}$.

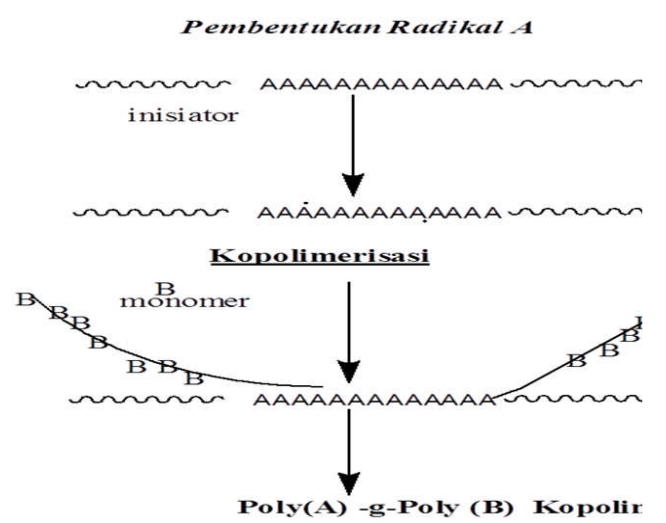

Gambar 3. Mekanisme reaksi cangkok monomer vinil pada polisakarida [18]

Pada awalnya sebagai efek iradiasi yang terjadi pada campuran kalium akrilat-gelatin dengan terjadinya reaksi radiolisis air membentuk $\mathrm{H}$ dan $\mathrm{OH}$ radikal (reaksi 2). Selanjutnya $\mathrm{H}$ atau $\mathrm{OH}$ radikal bereaksi dengan asam akrilat yang tersisa membentuk radikal asam akrilat (reaksi 3) dan selanjutnya mengalami reaksi polimerisasi membentuk homopolimer (reaksi 4) yang larut dalam air. Selain itu, radikal asam akrilat bereaksi secara ikatan silang dengan radikal kalium akrilat membentuk kopolimer yang stabil. Pada saat yang bersamaan gelatin juga mengalami proses pembentukkan radikal (reaksi 7) akibat iradiasi gamma sebagai radikal gelatin. Pada reaksi terminasi, radikal ikatan silang kopolimer asam akrilat sebagai P radikal tercangkok (grafting) pada punggung molekul gelatin radikal membentuk hidrogel superabsorben melalui reaksi ikatan silang (reaksi 8). Hal ini terlihat jelas pada fotomikrograf SEM yang disajikan pada Gambar 1 dan Gambar 2. Pada konsentrasi gelatin $1 \%$, kemungkinan sebagian gelatin ikut serta dalam reaksi kopolimerisasi yang mengakibatkan pori kopolimer menjadi besar. Sedangkan pada konsentrasi gelatin $4 \%$ dalam HSA, ikatan silang pada polimer membentuk jaringan ikatan silang yang merata dan gelatin terpisah secara jelas dari jaringan kopolimer (Gambar 2).

\section{Kinetika Rasio Swelling Hidrogel}

Pengaruh konsentrasi gelatin terhadap kemampuan swelling hidrogel superabsorben kopoli(kalium akrilat)-g-gelatin sebagai fungsi waktu perendaman disajikan pada Gambar 5. Terlihat bahwa pada waktu perendaman awal 5 menit pertama, semua hidrogel menunjukkan kapasitas absorbsi air yang relatif besar dengan kisaran $500 \mathrm{~g} / \mathrm{g}$ hingga $750 \mathrm{~g} / \mathrm{g}$. Meningkatnya waktu perendaman hingga 35 menit disertai dengan meningkatnya konsentrasi gelatin hingga $4 \%$, rasio swelling hidrogel meningkat secara perlahan-lahan (gradually) dan selanjutnya mengalami kondisi yang relatif konstan pada kisaran $680 \mathrm{~g} / \mathrm{g}$ hingga $800 \mathrm{~g} / \mathrm{g}$. Gelatin merupakan salah satu derivat protein yang sepanjang rantai punggung polimer terdiri dari 


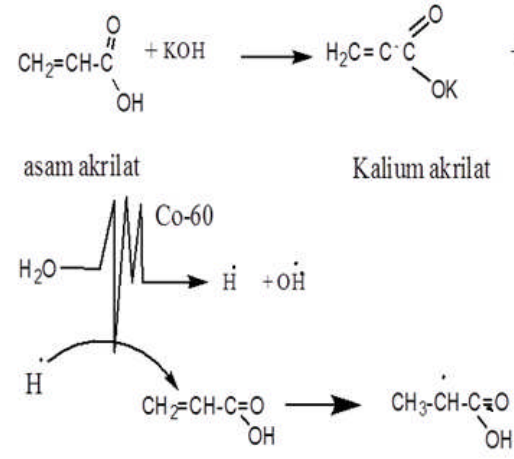

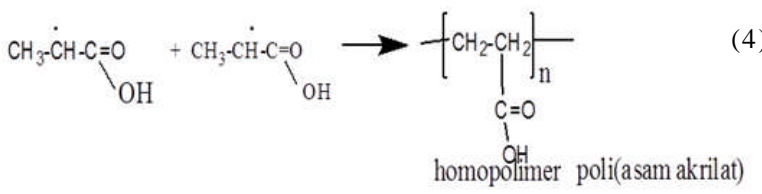

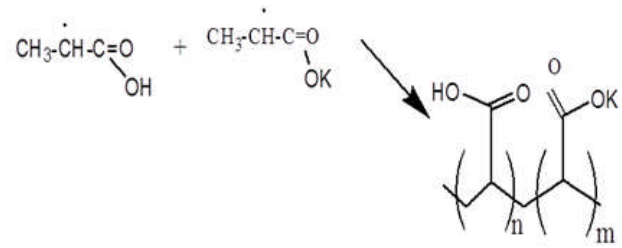
crosslinking

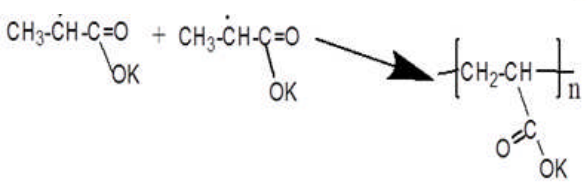
Homopolimer poli(kalium akrilat)

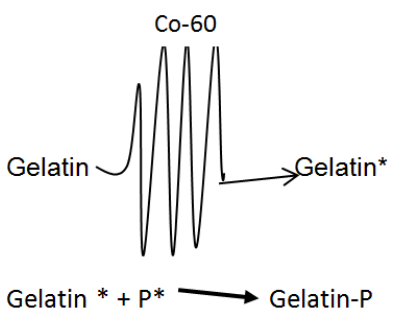

Gambar 4. Asumsi mekanisme reaksi cangkok kopoli(kalium akrilat)-gelatin pada proses iradiasi gamma.

gugus-gugus amino $(\mathrm{NH})$ dan asam karboksilat $(\mathrm{COOH})$ yang memungkinkannya dapat berinteraksi dengan molekul membentuk ikatan hidrogen disamping poli(kalium akrilat) sebagai basis hidrogel superabsorben. Hal ini mungkin menyebabkan dengan meningkatnya konsentrasi gelatin, kemampuan menyerap airnya meningkat.

\section{Fraksi gel HSA}

Jika suatu campuran yang mengandung monomer yang peka terhadap iradiasi gamma (asam akrilat) untuk berikatan silang dan polimer yang mudah mengalami degradasi (gelatin), maka umumnya terdapat 2 jenis produk hasil reaksi yang terjadi yaitu terbentuk hidrogel

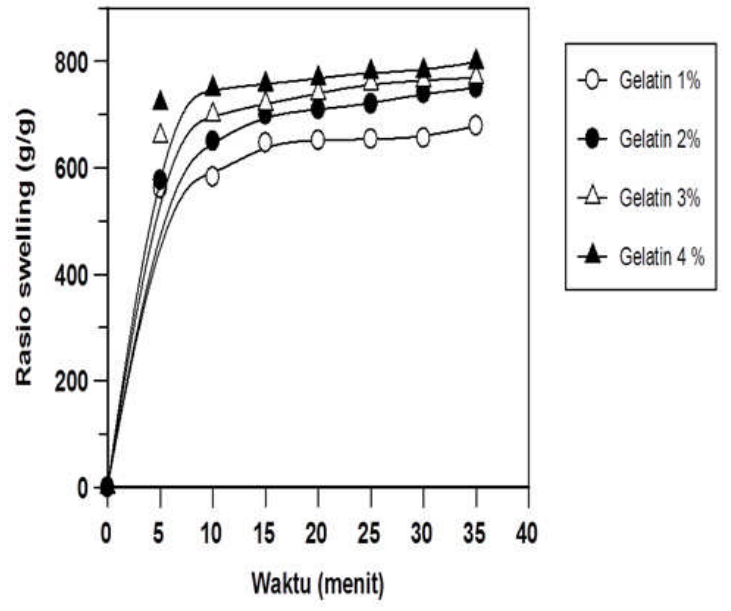

Gambar 5. Kinetika swelling hidrogel kopoli(kalium akrilat)-g-gelatin yang dipreparasi dengan konsentrasi variasi gelatin hasil iradiasi gamma.

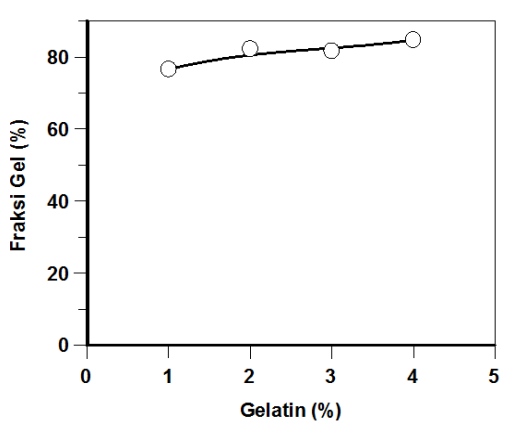

Gambar 6. Hubungan konsentrasi gelatin terhadap fraksi gel hidrogel kopoli( kalium akrilat)-g-gelatin hasil iradiasi $10 \mathrm{kGy}$.

atau tidak terbentuk hidrogel (berbentuk larutan). Hidrogel terbentuk jika konsentrasi asam akrilat lebih besar dibandingkan gelatin atau sebaliknya tidak terbentuk hidrogel. Pada umumnya untuk menentukan efisensi bahan awal baik berupa campuran atau bahan tunggal yang dirubah menjadi produk hidrogel hasil iradiasi gamma digunakan parameter fraksi gel [17]. Pengaruh konsentrasi gelatin dari $1 \%$ hingga $4 \%$ terhadap fraksi gel hidrogel poli(kalium akrilat-g-gelatin) disajikan pada Gambar 6. Terlihat bahwa dengan meningkatnya konsentrasi gelatin hingga $4 \%$, fraksi gel hidrogel meningkat dari $76 \%$ hingga $85 \%$. Hal ini mungkin disebabkan polimer (kalium akrilat) yang tercangkok pada punggung gelatin meningkat selama proses iradiasi.

\section{Equilibrium Degree of Swelling HSA}

Equilibrium Degree of Swelling (EDS) hidrogel adalah salah satu parameter yang juga penting untuk mempelajari kondisi air yang terserap dalam hidrogel dicapai selama proses air keluar masuk hidrogel melalui pori-pori hingga kondisi setimbang. Gugus hidrofilik (asam akrilat dan gelatin) yang menyebabkan absorpsi air pada hidrogel yaitu gugus $\mathrm{OH}$ (hidoksi) atau asam 


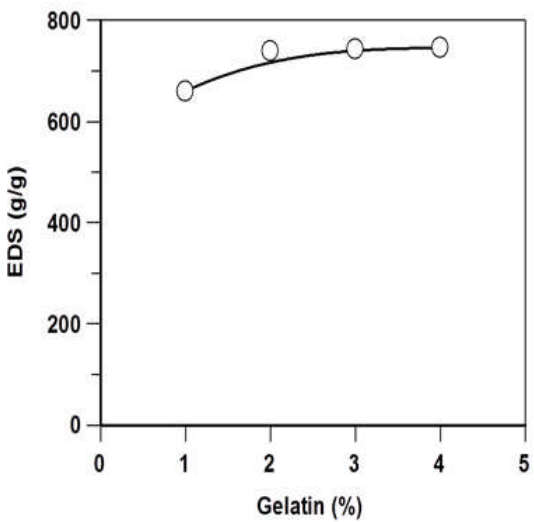

Gambar 7. Pengaruh konsentrasi gelatin vs. air setimbang hidrogel (EDS)

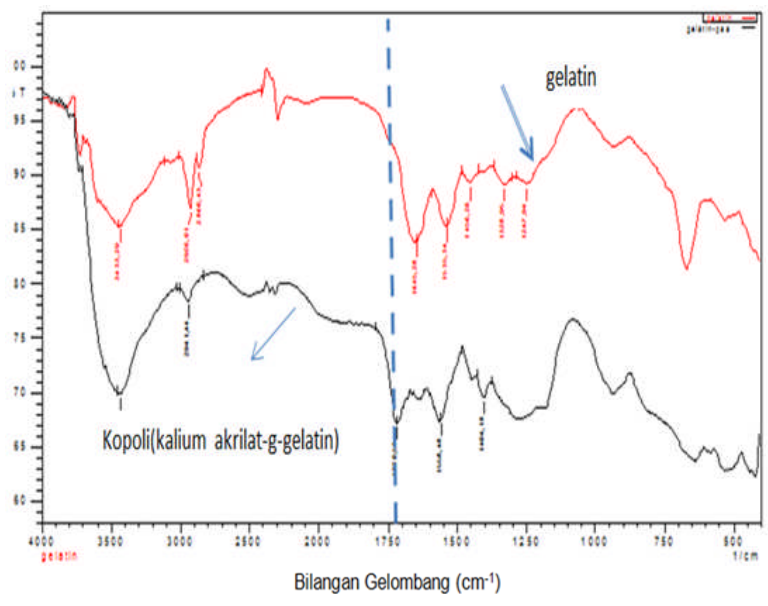

Gambar 8. Spektrum FT-IR gelatin dan hidrogel kopoli(kaliumakrilat-g-gelatin) hasil iradiasi gamma.

$(\mathrm{COOH})$ yang terikat pada polimer dan $\mathrm{NH}_{2}$ pada gelatin serta gugus karboksilat (COOH). Jika hidrogel direndam dalam air, air masuk ke dalam hidrogel melalui tekanan osmosis dan atom hidrogen bereaksi dan menghasilkan ion positif. Hal ini menyisakan ion negatif sepanjang rantai polimer. Ion-ion negatif tersebut saling tolak menolak dan menyebabkan rantai menjadi terbuka lebar dan menarik molekul air dan mengikatnya melalui ikatan hidrogen [18]. Proses ini berlansung hingga mencapai keadaan kesetimbangan.

Spektrum FT-IR gelatin dan hidrogel kopoli(kaliumakrilat-g-gelatin hasil iradiasi gamma disajikan pada Gambar 8. Terlihat bahwa gugus fungsi $\mathrm{NH}$ tekuk dari gelatin terletak pada daerah bilangan gelombang $3400 \mathrm{~cm}^{-1}$, gugus fungsi $\mathrm{C}-\mathrm{H}$ ulur tampak timbul pada bilangan gelombang $3100 \mathrm{~cm}^{-1}$ hingga $2800 \mathrm{~cm}^{-1}$, gugus fungsi $\mathrm{C}=\mathrm{O}$ ulur (ikatan peptida) tampak pada bilangan gelombang 1660 hingga 1600, gugus C-N-H tekuk tampak pada bilangan gelombang $1565 \mathrm{~cm}^{-1}$ hingga $1500 \mathrm{~cm}^{-1}$ dan gugus $\mathrm{C}-\mathrm{H}$ tekuk terletak pada bilangan gelombang $1450 \mathrm{~cm}^{-1}$ hingga $1300 \mathrm{~cm}^{-1}$ [19]. Puncak yang lain timbul pada gelatin adalah gugus $\mathrm{CO}_{2}$-yang timbul pada daerah bilangan gelombang $1720 \mathrm{~cm}^{-1}$ dalam hidrogel kopoli(kalium akrilat-g-gelatin) yang menunjukkan terjadinya cangkok (graft) pada gelatin [9].

\section{KESIMPULAN}

Dari penelitian dapatlah disimpulkan bahwa hidrogel superabsorben poli(kalium akrilat-g-gelatin) dapat dicangkokan pada gelatin dengan teknik iradiasi gamma pada dosis $10 \mathrm{kGy}$. Hasil pengujian spektrum $F T-I R$ menunjukkan bahwa terjadi pencangkokan gelatin oleh polimer (polikalium akrilat) pada gelatin. Pada observasi morfolgi (SEM) hidrogel secara visual terlihat dua fasa terbentuknya grafting polimer pada gelatin dan struktur pori yang memungkin hidrogel menyerap air. Meningkatnya konsentrasi gelatin menyebabkan rasio swelling dan fraksi gel hidrogel meningkat.

\section{UCAPAN TERIMA KASIH}

Ucapan terima kasih disampaikan kepada Bapak Bonang dan Nurazin yang telah membantu iradiasi hingga penelitian ini selesai.

\section{DAFTAR ACUAN}

[1]. E.M.Ahmed. "Hydrogel: Preparation,CharacteriZation and Application". A review. Journal of Advanced Research, vol. 6, pp 105-121, 2015.

[2]. Y. Li, G. Huang, X. Zhang, B. Li, Y.Chen, T. Lu, T. J. $\mathrm{Lu}$ and F. Xu. "Magnetic Hdrogels and Their Potential Biomedical Applications". Adv Funct Mater, vol. 23, no. 6, pp. 660-672, 2013,

[3]. I. Azman, S.A. Mutalib and S.F.M. Yusoff. "Novel Dioscorea Hispida Starch-Baed Hydrogels and Their Beneficial Use as Disinfectants". J Bioact Compat Polym, vol. 31, pp 42-59, 2016.

[4]. F. M. Francesco, A. Parente, P. Santaman, A. Sannino and F. Seno. "Biodegradable Superabsorbent Hydrogel Increases Water Retention Properties of Growing Media and Plant Growth". Agriculture and Agricutural Science, vol. 4, pp. 451-458, 2015.

[5]. Z. Wen, J. Xing, C. Yang, L.Yuying, F. Jun. "Degradable Natural Polymer Hydrogels for Articular Cartilage Tissue Engineering”. J Chem Technol Biotechnol, vol. 88, no. 3, pp. 327-339, 2013.

[6]. D. R. Barleany R. S. D. Lestari, M. Yulvianti, T. R. Susanto, Shalina, Erizal. "Acrylic Acid Neutralization for Enhancing The Production of Grafted Chitosan Superabsorbent Hydrogel". International Journal on Advanced Science, Engineering and Information Technology, vol. 7, no. 2, pp. 482-486, 2017.

[7]. O. M. Jensen. "Use of Superabsorbent Polymers in Concrete". Concrete International, pp. 48-52, January 2013 
[8]. L. Esteves. "Superabsorbent Polymers: on Their Interaction with Water and Pore Fluid". Cement and Concrete Composites, vol. 33, no. 7, pp. 717-724, 2011.

[9]. S. Kato, F. Kishiro, O. Yokohagi, F.S. Vijayanand. "Synthesis of Novel Biodegradable Superabsorbent Polymer Using Chitosan For Desert Land Development". Journal of Arid Land Studies, vol. 27, no. 2, pp. 67-74, 2017.

[10]. Erizal, F. Lukitowati, I. Oktaviani, D. R. Barleany. "Synthesis and Characterization of Superabsorbent Sodium Alginate-g-poly (potassium acrylate) Hydrogels Prepared by Using Gamma Irradiation". Jurnal Kimia dan Kemasan, vol. 39, no. 1, pp. 9-16, 2017.

[11]. A. Kalhapure, R. Kumar, V.P. Singh and D.S. Pandey. "Hydrogels: A boon for Increasing Agricultural Productivity in Waterstressed Environment". Current Science, vol. 111, no.11, pp. 1773-1778, 2016.

[12]. S. Shani and M. J. Z. H. Omidian. "Anti Bacterial Superabsorbent Hydrogels with High Saline Swelling Properties Without Gel Blockage" :Toward Ideal Superabsorbent for Hygenic Application. Journal Bioactive and composite polymers, vol. 32, no. 2, pp. 128-145, 2016.

[13]. B. Cheng, B. Pei, Z. Wang and Q. Hu. "Advances in Chitosan-Based Superabsorbent Hydrogels". RSC.Adv., vol. 7, pp. 42036-42046, 2017

[14]. A. A. L. Gonçalves, A. C. Fonseca, I. G. P. Fabela, J. F. J. Coelho and A. C. Serra. "Synthesis and
Characterization of High Performance SuperAbsorbent Hydrogels Using bis[2-(methacryloyloxy)ethyl]phos-phate as Crosslinker". eXPRESS Polymer Letters, vol. 10, vol. 3, pp. 248-258, 2016.

[15]. R. Duan, J. Zhang, X. Dua, X. Yao and K. Konno.'Properties of Collagen from Skin, Scale and Bone of Carp (Cyprinus carpio)". Food Chem., vol. 112, no. 3, pp. 702-706, 2009.

[16]. Erizal, D.P. Perkasa, G.S. Sulistioso, Sudirman, Z. Juniarti, Hariyanti. "Sintesis dan Karakterisasi Biodegradabel Hidrogel Superab-Sorbent Poli(kalium akrilat)-g-glukomanan dengan Teknik Iradiasi Gamma”. Jurnal Sains Materi Indonesia, vol. 19, no. 1, pp 32-38, 2017.

[17]. R. S. Tomar, I. gupta, R. Singhai, A. K. Nagpal." Synthesis of poly(acrylamide-co-Acrylic acid) Based Superabsorbent Hydrogels By Gamma Radiation : Study of Swelling Behaviour and Network Parameters". Designed Monomers and Polymers, vol. 10, no. 1, pp. 49-66, 2007.

[18]. A. Kalhapure, R. Kumar, V.P. Singh and D.S. Pandey. "Hydrogels : A Boon for Increasing Agricultural Productivity in Water-Stressed Environment". Current scienc, vol. 111, no. 11, pp. 1773-1779, 2016.

[19]. Hermanto, S., Sumartin, L.O., Fatimah, W. "Differentation of Boxine and Porcine Gelatin Based on Spectroscopic and Electrophoretic Analysis". J. Food Pharm. Sci, vol. 1, no. 3, pp. 68-73, 2013. 